\begin{tabular}{cc|c|}
\hline CARstitute & $\begin{array}{c}\text { CADDE: Jurnal Pengabdian Kepada Masyarakat } \\
\text { https://journal.ilininstitute.com/index.php/caradde } \\
\text { Volume 1 I Nomor 1 I Agustus | } 2018 \\
\text { e-ISSN: 2621-7910 dan p-ISSN: } 2621-7961 \\
\text { DOI: https://doi.org/10.31960/caradde.v1i1.3 }\end{array}$ \\
\hline
\end{tabular}

\title{
Training of Scientific Papers Writing On Students of Widya Dharma University
}

\section{Bayu Purbha Sakti}

\author{
Keywords : \\ Scientific papers, \\ Training of writing, \\ Student training.
}

\section{Corespondensi Author}

Pendidikan Guru Sekolah Dasar

Universitas Widya Dharma Klaten

Mutihan Gantiwarno Klaten

Email: bayups@unwidha.id

\section{History Artikel}

Received: Juni-2018;

Reviewed: Juli-2018

Accepted: Juli-2018

Published: Agustus-2108

\begin{abstract}
This community service activities are done because the author wants students to have the ability to write their ideas to the public or community at large. The purpose of this activities is to provide skill to arrange scientific papers on students from Elementary School Teacher Education Study Program of Widya Dharma Univertsity by organizing scientific papers writing workshop. The benefits of this activities is to provide skills to students in preparing quality scientific papers and arrange forums to exchange ideas between the students and universities in terms of preparation for students in developing scientific papers. The method used is lecture method, discussion, answer question, and presentation. Several factors affecting the training activities of the scientific paper writing are the participants become interested to follow the training activities so that activities are expected to take place smoothly, this activities makes the participants to understand the scientific papers much better as important thing berfore they arrange the tesis, and the increased support and motivation from the Research and Community Service Institute of Unwidha so that future training activities can run smoothly. The manual book will be very necessary for students in arranging scientific papers so that students have scientific papers according to Unwidha's papers. Unwidha lectures are expected to hold some student training so that students are more competents when they enter the workspace. The manual book will be very necessary for students in arranging scientific papers so that students have scientific papers according to Unwidha's papers. Unwidha lecturers are expected to hold some student training so that students are more competent when they enter the workforce.
\end{abstract}

This work is licensed under a Creative Commons Attribution

4.0 International License

\section{PENDAHULUAN}

Ada 8 perusahaan yang merasakan kesulitan merekrut lulusan perguruan tinggi di Indonesia. Beberapa perusahaan tersebut menginginkan tenaga kerja yang siap untuk digunakan. Willis Tower Watson menjelaskan bahwa Data Badan Pusat Statistik (BPS) menunjukkan pengangguran sarjana di Indonesia meningkat dari 653.586 pada Agustus 2015 menjadi 695.304 orang pada Februari 2016 (Amiranti, 2016). Pihak perguruan tinggi sebaiknya mempersiapkan pencetakan generasi sarjana yang siap bekerja 
di perusahaan. Materi yang ada di perkuliahan sebaiknya disusun mengarah ke dunia kerja.

Para mahasiswa diharapkan memiliki inovasi selain mereka akan memasuki dunia kerja. Ada beberapa mahasiswa yang menunjukkan karyanya sampai ke luar negeri. Contoh dari inovasi tersebut adalah inovasi kedua mahasiswa asal Padang yang mengubah cita rasa kerupuk asal Kecamatan Kamang Magek Kabupaten Agam itu menjadi sesuatu yang berbeda. Kerupuk Kamang merupakan makanan lokal khas Minang yang dikenalkan Dua mahasiswa asal Universitas Andalas (Unand) Padang, Sumatera Barat, Sari Rahayu dan Okti Diana Bahrun pada negara Turki beberapa waktu lalu (Subekti, 2016).

Kedua mahasiswa asal Padang itu bisa pergi menuju Turki karena produk Kerupuk Kamang diapresiasi di Turki. Mereka berangkat menuju ke Turki didampingi dan dibimbing oleh Pejabat Rektorat Universitas Andalas. Mereka menyampaikan inovasinya dengan disertai makalah.

Mahasiswa dihadapkan menulis makalah dan karya ilmiah untuk mengembangkan potensi intelektual dan kreativitas di masa depan. Sarjana diharapkan mempunyai ketrampilan dalam penulisan karya dengan bukti yang ilmiah. Direktur Jenderal Pendidikan Tinggi Kementerian Pendidikan dan Kebudayaan (Dirjen Dikti Kemdikbud), Djoko Santoso menjelaskan bahwa seluruh mahasiswa (S-1, S-2, S-3) diwajibkan membuat dan mempublikasikan tulisan karya ilmiahnya sebagai salah satu penentu kelulusan (Akuntono, 2012). Seorang sarjana harus memiliki kemampuan ilmiah dalam menulis karyanya. Seorang sarjana harus menguasai tata cara dalam menulis karya ilmiah. Seorang mahasiswa harus menulis karya secara ilmiah dari rangkuman tugas, lapiran yang dibuat, penelitian kecil, dan dari skripsi yang dikerjakan.

Proses kegiatan pembelajaran yang dialami oleh mahasiswa memang identik dengan penulisan karya ilmiah dan artikel. Penulisan karya ilmiah diberlakukan di Universitas Ganesha (Undiksha). Mahasiswa harus memiliki ketrampilan menulis karya ilmiah sebagai syarat menyelesaikan studi pada jenjang pendidikan D3, S1, S2, maupun
S3 (Suandi, 2016). Pihak Undiksha meminta mahasiswa untuk mengembangkan diri melalui artikel tulisan di surat kabar dan majalah. Mahasiwa Undiksha diharuskan berani menulis mengenai kondisi alam lingkungan sekitar. Mahasiwa Undiksha diharapkan belajar melebihi membaca dan mendengarkan bahkan menulis gagasan atau ide supaya dipublikasikan. Mahasiswa dapat menulis dari beragam kegiatan akademis dan nonakademis di kampus akan membuat mahasiswa aktif sekaligus belajar banyak mengenai organisasi.

Mahasiswa diharapkan memacu belajar menulis di surat kabar. Apalagi kalau menulis itu dimasukkan ke dalam tugas akhir mata perkuliahan tertentu. Mereka menjadi lebih bersemangat mencari nilai, sambil belajar memunculkan tulisannya ke publik. Penilaian yang dilaksanakan kegiatan perkuliahan sangat beragam. Penilaian itu juga akan diterapkan mahasiswa yang sudah lulus dalam dunia kerja. Penilaian dilakukan secara konsisten dan sistematik dengan menggunakan tes dan nontes dalam bentuk tertulis atau lisan, pengamatan kinerja, pengukuran sikap, penilaian hasil karya berupa tugas, proyek dan/atau produk, portofolio, dan penilaian diri (Sakti, 2016b).

Lulusan Perguruan Tinggi dituntut untuk memiliki academic knowledge, skill of thinking, management skill, dan communication skill (Musmeinan, 2016). Tuntutan academic knowledge yaitu mahasiswa diharuskan memiliki pengetahuan akademik yang baik. Tuntutan skill of thinking yaitu mahasiswa diharuskan memiliki ketrampilan dalam berpikir dan alangkah lebih baik jika mahasiswa dapat memiliki high order thinking. Tuntutan management skill yaitu mahasiswa diharuskan memiliki ketrampilan dalam mengolah dan mengendalikan berbagai kebutuhannya sebagai mahasiswa perguruan tinggi. Tuntutan communication skill yaitu mahasiswa diharuskan memiliki ketrampilan dalam berkomunikasi dengan menggunakan berbagai metode. Penyusunan karya ilmiah merupakan bagian dari skill of thinking.

Karya ilmiah disusun sebagai langkah awal untuk menyusun penelitian. Para mahasiswa Program Studi Pendidikan Guru Sekolah Dasar Universitas Widya Dharma (Unwidha) diharapkan memiliki wawasan dan pengetahuan dalam penyusunan karya ilmiah. 
Sakti. Training of Scientific paper...

Mereka akan terbiasa menulis karya ilmiah dengan benar jika mereka dapat memahami proses penyusunan karya ilmiah. Penyusunan karya ilmiah dibuat sebagai kemiripan dari penyusunan artikel, proposal, dan karya tulis ilmiah lainnya. Penyusunan karya ilmiah akan membiasakan para mahasiswa dalam kegiatan menulis dan nantinya mereka juga tidak kesulitan dalam mengerjakan skripsi. Artikel dan jurnal yang ditulis merupakan tuntutan formal akademik serta memiliki kedudukan dan peran yang sangat penting (Bustami, 2017).

Kegiatan pengabdian masyarakat ini bertujuan untuk memberikan pengetahuan dan keterampilan menyusun karya ilmiah pada mahasiswa Program Studi (Prodi) Pendidikan Guru Sekolah Dasar Universitas Widya Dharma. Kegiatan pengabdian masyarakat ini dinamai pelatihan penulisan karya ilmiah yang dilaksanakan mahasiswa Prodi PGSD. Oleh karena itu, para mahasiswa tersebut diharapkan mampu menggali dan menemukan kreativitas dalam penyusunan makalah.

Meningkatkan minat baca harus dimulai dari masa kanak-kanak sampai masa sekolah dasar (Sakti, 2017a). Hal inilah yang menyebabkan mahasiswa Program Studi Pendidikan Guru Sekolah Dasar Universitas Widya Dharma harus menghasilkan karyakarya supaya dipahami anak sekolah dasar. Guru sekolah dasar memiliki peranan penting demi terciptanya kondisi siswa yang lebih baik (Sakti, 2016a).

Manfaat yang diharapkan dari kegiatan pengabdian berupa pelatihan ini adalah (1) Memberikan keterampilan kepada mahasiswa dalam menyusun karya ilmiah yang berkualitas. (2) Sebagai forum untuk bertukar pikiran antara pihak mahasiswa dengan perguruan tinggi dalam hal persiapan bagi mahasiswa dalam mengembangkan karya ilmiah.

\section{METODE}

Metode yang digunakan dalam pengabdian masyarakat ini adalah pemberian pelatihan dengan beberapa metode yang digunakan. Metode penyampaiannya adalah metode ceramah, diskusi, tanya jawab, dan presentasi. Metode ceramah diberikan oleh penulis dalam menjelaskan materi pengabdian masyarakat dengan materi berupa penulisan karya ilmiah. Metode disikusi harus dilakukan oleh peserta pengabdian masyarakat yang berguna untuk memahami materi penulisan karya ilmiah. Metode Tanya jawab wajib dilakukan peserta pengabdian masyarakat supaya terdapat upaya timbal balik pemahaman yang berkaitan dengan materi penulisan karya ilmiah. Metode presentasi dilakukan peserta pengabdian masyarakat untuk membuktikan hasil kreasi materi penulisan karya ilmiah. Dua puluh dua Peserta pengabdian diharapkan menyusun proposal karya ilmiah sebagai hasil dari kegiatan pengabdian masyarakat ini. Alat yang digunakan peserta dalam kegiatan pengabdian masyarakat adalah komputer atau laptop, sistem operasi Windows 7, dan Microsoft Office Powerpoint 2010.

\section{HASIL DAN PEMBAHASAN}

Hasil yang dicapai dari kegiatan pengabdian masyarakat dengan materi berupa penulisan karya ilmiah ini membuat para mahasiswa sebagai peserta memiliki minat yang besar untuk menulis karya ilmiah, mereka menganggap karya ilmiah ini penting, dan pencapaian target dari kegiatan ini dapat dilakukan. Hasil tersebut akan dibahas dan dijelaskan sebagai berikut.

1. Minat peserta yang mengikuti kegiatan pelatihan penulisan karya ilmiah

Peserta yang mengikuti pelatihan penulisan karya ilmiah ini adalah para mahasiswa Program Studi Pendidikan Guru Sekolah Dasar Universitas Widya Dharma Klaten. Para mahasiswa tersebut diharapkan akan memiliki keahlian mengimplementasikan karya ilmiahnya di sekolah dasar. Program studi pendidikan guru sekolah dasar merupakan program studi (prodi) yang mengarahkan mahasiswa untuk memiliki keahlian di bidang sekolah dasar (Sakti, 2017b).

Jumlah peserta yang mengikuti kegiatan pelatihan sebanyak 22 mahasiswa. Mereka berminat untuk mengikuti kegiatan pelatihan ini dan memiliki keinginan. Keinginan mereka ialah mengikuti lomba karya tulis tingkat mahasiswa baik yang diselenggarakan tingkat lokal, regional, atau 
nasional.

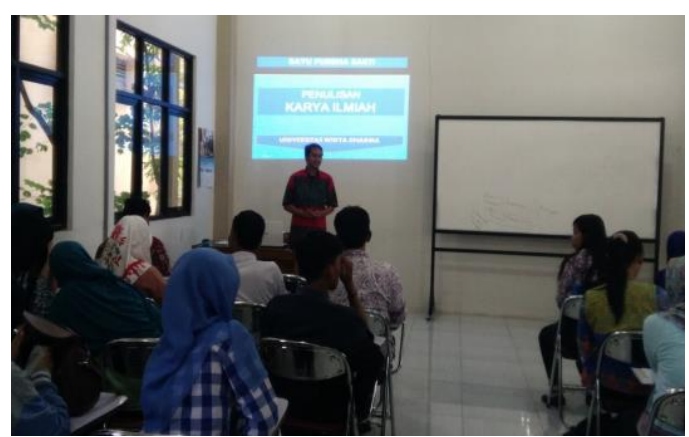

Gambar 1: Penulis memberi arahan pelatihan

2. Urgensi karya ilmiah yang dipahami peserta kegiatan

Penulis memberikan arahan kepada peserta kegiatan pelatihan penulisan karya ilmiah bahwa kegiatan ini memiliki makna yang penting. Skripsi adalah tugas akhir yang harus dijalani mahasiswa sebelum lulus menjadi sarjana. Skripsi merupakan salah satu dari karya ilmiah. Oleh karena itu para peserta harus memiliki pengetahuan yang berkaitan dengan hal-hal yang diperlukan dalam penyusunan skripsi atau karya ilmiah. Sebagai contoh yaitu ada penulisan kalimat fakta yang memiliki sumber yang harus ditulis di daftar pustaka. Hal tersebut menuntut para peserta untuk memiliki kecermatan dan ketelitian dalam kegiatan penulisan karya ilmiah maupun skripsi.

Guru diharapkan mampu mencari informasi di buku, internet, dan seminar supaya guru memiliki inovasi mengajar (Sakti \& Wijayanti, 2014). Para peserta yang mengikuti pelatihan penulisan ini adalah calon guru sekolah dasar. Oleh karena itu, para peserta diharapkan memiliki kemampuan untuk membaca, menyimak, menulis, mengolah, dan membicarakan informasi yang bersumber dari buku, internet, dan seminar.

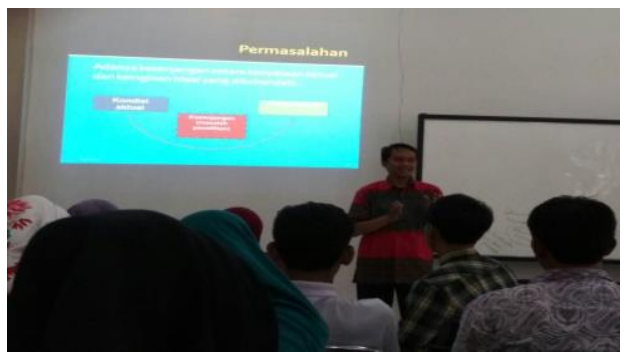

Gambar 2: Penulis memaparkan permasalahan karya ilmiah
3. Pencapaian kegiatan pelatihan penulisan karya ilmiah

Target dari kegiatan pelatihan penulisan karya ilmiah ini adalah penyusunan proposal karya ilmiah. Para peserta kegiatan pelatihan ini mengaku jika mereka kesulitan dalam merancang latar belakang karya ilmiahnya. Penulis sebagai pemateri kemudian memberikan contoh latar belakang dari proposal karya ilmiah yang lain. Ketika para peserta kegiatan pelatihan membaca dan memahami contoh dan sistematika karya ilmiah maka mereka dapat menulis karya ilmiah. Pengelompokkan peserta kegiatan pelatihan perlu dilakukan untuk mempermudah dan mempercepat penyusunan proposal karya ilmiah. Terdapat 4 kelompok yang mampu membuat proposal karya ilmiah. Ada beberapa masalah yang dihadapi dalam kegiatan pelatihan ini diantaranya (1) motivasi para peserta kegiatan pelatihan yang menurun ketika mereka merasa tidak mampu untuk melanjutkan penyusunan proposal, (2) ada beberapa peserta yang mengeluh terhadap waktu yang dijalani berkaitan dengan penyusunan proposal yang berbenturan dengan kegiatan non akademik di kampus, (3) ada beberapa peserta yang kurang teliti dalam memahami sistematika penulisan karya ilmiah. Pihak Lembaga Penelitian dan Pengabdian Masyarakat Unwidha sangat mendukung dengan kegiatan pelatihan yang dilakukan ini. Mereka mengasumsikan kegiatan ini sebagai bentuk kegiatan pembelajaran dan pembimbingan kepada mahasiswa sebelum mereka mengerjakan tugas akhir yang sesungguhnya.

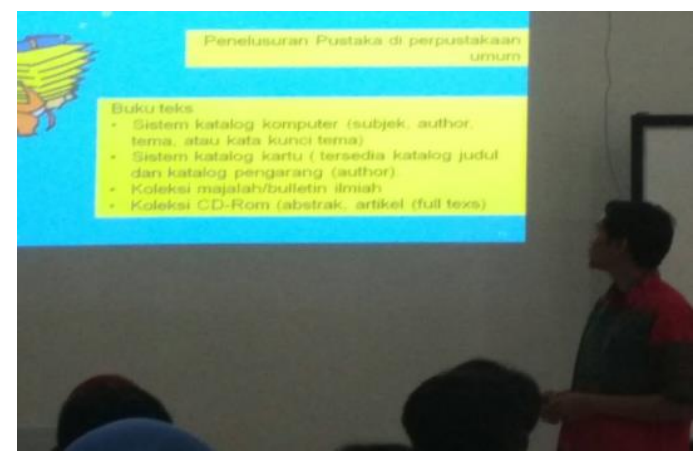

Gambar 3: Penulis menjelaskan referensi karya ilmiah 
Sakti. Training of Scientific paper...

\section{SIMPULAN DAN SARAN}

Kegiatan pengabdian masyarakat ini membuat penulis memiliki pengalaman yang berharga. Beberapa faktor yang mempengaruhi kegiatan pelatihan penulisan karya ilmiah ini adalah para peserta menjadi berminat untuk mengikuti kegiatan pelatihan sehingga kegiatan diharapkan dapat berlangsung dengan lancar, kegiatan ini menjadikan para peserta untuk lebih memahami karya ilmiah sebagai hal yang penting sebelum mereka menyusun skripsi, dan meningkatnya dukungan dan motivasi dari pihak Lembaga Penelitian dan Pengabdian Masyarakat Unwidha sehingga kegiatan yang akan datang dapat berjalan lancar. Buku pedoman akan sangat diperlukan mahasiswa dalam menyusun karya ilmiah supaya mahasiswa memiliki karya ilmiah sesuai karya Unwidha. Para dosen Unwidha diharapkan mengadakan beberapa pelatihan mahasiswa supaya para mahasiswa lebih berkompeten ketika mereka memasuki dunia kerja.

\section{DAFTAR RUJUKAN}

Akuntono, I. (2012). Ini Alasan Mahasiswa Wajib Publikasi Makalah Kompas.com. Retrieved July 9, 2018, from https://edukasi.kompas.com/ read/ 2012/ 02/ 03/ 15160740/ Ini. Alasan. Mahasiswa. Wajib.Publikasi.Makalah.

Amiranti, C. C. (2016). Jangan Asal Kuliah... Ijazah Sarjana Saja Tak Cukup Buat Kerja! - Kompas.com. Retrieved July 9, 2018, from https://edukasi.kompas.com/ read/ 2016/ 11/ 25/ 06310081/ jangan. asal. kuliah. ijazah. sarjana. saja. tak. cukup. buat.kerja.

Bustami. (2017). Panduan Penulisan Jurnal Tahun 2017 (p. 9). Medan: Unsam Press. Retrieved from https://lppm.unsam.ac.id/ wp-content/ uploads/ 2017/ 02/ Panduan_ Penulisan_Jurnal. pdf. pdf

Musmeinan, I. A. (2016). Pedoman Program Kreativitas Mahasiswa (PKM) Tahun 2016 (p. 117). Jakarta: Kementerian Riset, Teknologi, dan Pendidikan Tinggi. Retrieved from http://belmawa.ristekdikti. go.id/ 2016/ 10/ 07/ penerimaan - proposal - pkm tahun - 2016-pendanaan - tahun - 2017/

Sakti, B. P. (2016a). Etika Dan Profesi Guru SD Di Tengah Perkembangan Zaman. Proceeding PGSD Universitas Kuningan 2016, 1(1), 99-107. Retrieved from https:// proceeding.uniku.ac.id/index.ph p/ pgsd2016/ article/ view/10

Sakti, B. P. (2016b). Indikator Sekolah Dasar Ramah Anak. Prosiding Seminar Nasional PKO FKIP UTP, 163-176. Retrieved from

http://ejournal.utp.ac.id/index.php/PR O PKO/ article/ view/ 596

Sakti, B. P. (2017a). Indikator Pengembangan Karakter Siswa Sekolah Dasar. Magistra Unwidha Klaten, 30, 1. Retrieved from http://journal. unwidha. ac. id/ index.php/MAGISTRA/ article/ view/ $1 / 0$

Sakti, B. P. (2017b). Persepsi Mahasiswa Program Studi Pendidikan Guru Sekolah Dasar Universitas Widya Dharma Tentang Etika Mahasiswa. Premiere Educandum: Jurnal Pendidikan Dasar Dan Pembelajaran, 7(02), 135. https://doi. org/ 10.25273/ pe.v7i2.1732

Sakti, B. P., \& Wijayanti, W. (2014). Implementasi Pembelajaran Tematik Pada SDN Di Gugus III Kecamatan Kalasan Kabupaten Sleman DIY. Jurnal Prima Edukasia, 2(1), 14. https://doi. org/ 10.21831/ jpe.v2i1.2641

Suandi, N. (2016). Pedoman Penulisan Karya Ilmiah Tugas Akhir, Skripsi, Tesis, Dan Disertasi. Bali: Undiksha Press. Retrieved from http://akademik.undiksha.ac.id/ wp-content/ uploads/ 2017/ 10/ Pedoman-Penulisan-Karya-Ilmiah2016.pdf

Subekti, R. (2016). Di Turki, Mahasiswa Padang Kenalkan Kerupuk Kamang Pojoksatu.id. Retrieved July 9, 2018, from http://pojoksatu.id/ pendidikan/ 2016/ 03/ 12/ di-turki-mahasiswapadang-kenalkan-kerupuk-kamang/ 